\title{
Effect of sorghum and methionine supplementation in productive performance and the quality of hatching eggs of two quail strains \\ D.Th.Younis
}

Department of Animal Resource, College of Agriculture and Forestry, Mosul University, Iraq.

E-mail:duraidthonnon@yahoo.com

Accepted on:8/6/2014

Summary

The aim of the present study was to identify the effect of corn replacement by sorghum and supplementation of methionine during growing and laying periods in productive performance and egg quality of two strains of quail (brown and black). Four hundred and eighty quails ( 240 of each strain) were used in this study. Birds were reared on floor letter in semi opened house distributed into four treatments each with three replicates ( 20 birds in replicate). Experimental treatments were as follows: T1: fed on yellow corn ration (Control), T2: fed on ration in which $50 \%$ of corn replaced by sorghum, T3: fed on ration in which $50 \%$ of corn replaced by sorghum and supplemented with $0.2 \%$ methionine and T4: fed on ration in which $50 \%$ of corn replaced by sorghum and supplemented with $0.4 \%$ methionine. Statistical analysis of data showed no significant differences $(\mathrm{P} \leq 0.05)$ between treatments and strains in live body weight, average weekly weight gain, feed consumption, feed conversion ratio dressing percentage and mortality rate. After sexual maturity age no differences were observed between the treatments and strains in egg production $\mathrm{HD} \%$, egg weight, feed conversion ratio, egg shape index, shell weight, shell thickness, albumin height, yolk dimension, yolk height, blood glucose, blood triglyceride, blood total protein, blood hemoglobin, ALT and AST enzymes concentration in serum through out of the experimental period which was lasted for 99 days. In conclusion, the results revealed the possibility of 50\% sorghum replacement instead of yellow corn without any passive effects on productive performance which reduce the productive costs.

Keywords: Grain Sorghum, Tannin, quail strain, Blood parameters, Egg quality.

Introduction

The poultry nutrition constitute about 65$70 \%$ of the total cost of poultry production. Because of that the development of poultry industry depends to large extent on the availability of feed stuffs that are used or can be made suitable for use in poultry nutrition. Yellow corn and soybean meal are the two major ingredients used in poultry nutrition. The availability of these two feed ingredients in some areas like Iraq is very costy. This has made poultry nutritionists in Iraq to search for local alternative low cost feed ingredients. Sorghum was available to cultivate especially in northern lraq in areas which are not suitable for yellow corn. One negative characteristic of sorghum is the presence of tannins which lower its nutritional value for non-ruminant animals by reducing protein retention, digestibility of dry matter and metabolic rate of gross energy (1). Also it is negatively affecting the animals performance and digestibility of feed (2).Tannin limit activities of some enzymes and microorganisms by forming complexes with nutrients and prevent their adsorbtion in the digestive system ( 3 and 4). Inhibition of digestive enzyme activity has also been reported (5 and 6).

Methionine is an essential nutrient for poultry. In addition, this amino acid provides methyl groups, which are needed for several metabolic reactions such as the synthesis of carnithine and creatine (7). Methionine is considered to be the first limiting amino acid in broilers fed Practical corn-soybean meal diets were meet the lysine and methionine requirement for broiler chicks. If the corn or soybean meal were replaced in the ration, adequate dietary supplementation with lysine or methionine were needed to support optimum growth and carcass yield of fastgrowing commercial broilers (8).

Materials and Methods

The experiment was carried out on 480 quails (Coturnix coturnix) belongs to two strains (Black and Brown) 240 birds/strain. 
Treatments were conducted for two periods, the $1^{\text {st }}$ period ( 7 weeks) from 1day untill 49days of age, the $2^{\text {nd }}$ period ( 7 weeks) from 50 days age till 99 days of age. The rations were calculated according to (9) and were given $a d$ Libitum with free excess drinking water .The sorghum content of tannin was determined according to (10) and the tannin values was $0.158 \%$ (the sorghum used was with low tannin content ). (Table, 1).

The quails (1day old) were distributed in 4 treatments, three replicates each (20 quail's) replicate) and reared on floor letter in semi opened house. The experimental treatments were as following:T1 : fed on standard ration (60\% corn) as Control group.T2: fed on ration in which $50 \%$ of the corn was replaced by sorghum.T3: fed on ration in which $50 \%$ of the corn was replaced by sorghum and supplemented with $0.2 \%$ methionine T4: fed on ration in which $50 \%$ of the corn was replaced by sorghum and supplemented with $0.4 \%$ methionine. In the $1^{\text {st }}$ period the evaluated parameters were: Live body weight (LW), weight gain (WG), Feed consumption (FC), Feed conversion ratio (FCR). After the end of $1^{\text {st }}$ period (age of 49 days) 2 birds from each replicate (6 birds/treatment group) were slaughtered ,blood collected and divided into two parts, the first part was collected in EDTA tubes and used for determination of packed cell volume (PCV\%) and hemoglobin $(\mathrm{Hb} / 100$ $\mathrm{ml}$ blood), the $2^{\text {nd }}$ part in plain tube and used to separate serum which stored at $(-20 \mathrm{C})$, Then used for determination of glucose $(\mathrm{mg} / \mathrm{dl})$, triglyceride $(\mathrm{mg} / 100 \mathrm{ml})$, total protein (mg/100ml), Aspartate amino transferase: AST $(\mathrm{u} / \mathrm{l})$ and Alanin amino transferase $\operatorname{ALT}(\mathrm{u} / \mathrm{l})$. The carcasses of birds were used to determine the dressing percentage. In the $2^{\text {nd }}$ period the productive parameters were recorded as: egg production $\mathrm{HD} \%$, egg weight $(\mathrm{g})$, feed conversion ratio ( $\mathrm{kg}$ feed $/ \mathrm{kg}$ egg). At the last week of treatments egg were collected from each group and used to determine the egg quality characters as: egg shape index, shell weight (gm), shell thickness (mm), albumin height $(\mathrm{mm})$, yolk height $(\mathrm{mm})$, yolk diameter $(\mathrm{mm})$, mortality of birds were recorded in both periods. Blood glucose $(\mathrm{mg} / 100 \mathrm{ml})$, blood triglyceride $(\mathrm{mg} / 100 \mathrm{ml})$, blood total protein (mg/100ml), blood hemoglobin (gm /100 ml), and assay of alanin and aspartate amino transferase in serum (ALT, AST) concentration (unit $/ \mathrm{ml}$ ). Data were analyzed by using the completely randomized design as described by (11 and 12) program were used in analysis data. The means in the difference were tested for statistical significance using Duncan's multiple range test as described by (13).

Table, 1: Composition and analyses of the experimental growing and Laying rations for quail, according to the nutritional requirements of NRC (1994).

\begin{tabular}{|c|c|c|c|c|c|c|}
\hline \multirow{2}{*}{$\begin{array}{l}\text { Treatments } \\
\text { Ingredients \% }\end{array}$} & \multicolumn{2}{|c|}{ Control } & \multicolumn{2}{|c|}{ Sorghum Replacemen } & \multicolumn{2}{|c|}{ Laying ration } \\
\hline & Starter & Finisher & Starter & Finisher & Control & Replacement \\
\hline Yellow Corn & 60 & 60 & 30 & 30 & 60 & 30 \\
\hline Sorghum & - & - & 30 & 30 & - & 30 \\
\hline Wheat & - & 9 & - & 9 & 10 & $\mathbf{1 0}$ \\
\hline Premix (40\% Protien) & 15 & 10 & 15 & 10 & 10 & 10 \\
\hline $\begin{array}{l}\text { Soybean Meal } \\
\text { (44\% } \% \text { Protien) }\end{array}$ & 24 & 20 & 24 & 20 & 16 & 16 \\
\hline Dicalcium Phosphate & 0.3 & 0.3 & 0.3 & 0.3 & 3.3 & 3.3 \\
\hline Sodium Chloride & 0.7 & 0.7 & 0.7 & 0.7 & 0.7 & 0.7 \\
\hline Total & 100 & 100 & 100 & 100 & 100 & 100 \\
\hline \multicolumn{7}{|c|}{ Calculated Analysis } \\
\hline $\begin{array}{l}\text { Metabolizable } \\
\text { Energy(Kcal/Kg) }\end{array}$ & 2875 & 2975 & 2845 & 2947 & 2909 & 2891 \\
\hline Crud Protien \% & 22.00 & 19.45 & 22.09 & 19.61 & 17.73 & 17.76 \\
\hline Ether Extraction \% & 3.40 & 3.395 & 3.265 & 3.170 & 3.098 & 2.798 \\
\hline Lysine \% & 1.360 & 1.1069 & 1.366 & 1.0949 & 1.358 & 1.268 \\
\hline Methionine \% & 0.8118 & 0.6155 & 0.8028 & 0.6065 & 0.6390 & 0.6150 \\
\hline Tannin \% & - & - & 0.0474 & 0.0474 & - & 0.0474 \\
\hline
\end{tabular}




\section{Results and Discussion}

Table (2) showed no differences between the treatments and strains in live body weight, weight gain and Feed Consumption .This result may be due to that the sorghum used in these treatments were low in tannin and the adaptation of birds on harm effect of tannin in sorghum on digestive tracts, therefore no effects were observed. Also the diets used were isocaloric and isonitrogenous. These results agreed with (14-16) who reported no differences in body weight and weight gain. (17 and 18) observed no differences in feed consumption for birds replaced corn by sorghum in ration. Also no difference was observed between the treatments and strains when the diets supplemented with methionine .The absence of difference is due to the diets methionine in ration according NRC. These results agreed with (19-21) who didn't observe differences between treatments due to supplementation of different levels of methionine to diet.

Table (3) showed no differences in feed conversion ratio, dressing percentage and mortality rate between treatments or strains .This may be due to that the percentage of sorghum replacement $50 \%$ didn't reach a harmful level, in addition to the adaptation of birds on low tannin percentage in sorghum. These results were in agreement with $(22$ and 23 ) in feed conversion ratio and with (8) in dressing percentage also (24) in feed conversion ratio and dressing percentage and mortality.

Table, 2: Effect of treatments in live weight, weight Gain, Feed Consumption for quail at 99 days old

\begin{tabular}{|c|c|c|c|c|c|c|}
\hline \multirow[b]{2}{*}{ Treatments } & \multicolumn{3}{|c|}{ Brown Strain } & \multicolumn{3}{|c|}{ Black Strain } \\
\hline & $\begin{array}{l}\text { Body } \\
\text { weight } \\
\text { (gm) }\end{array}$ & $\begin{array}{l}\text { Weight } \\
\text { gain } \\
\text { (gm) }\end{array}$ & $\begin{array}{c}\text { Feed } \\
\text { consumption } \\
(\text { gm) }\end{array}$ & $\begin{array}{c}\text { Body } \\
\text { weight } \\
\text { (gm) }\end{array}$ & $\begin{array}{l}\text { Weight } \\
\text { gain } \\
\text { (gm) }\end{array}$ & $\begin{array}{l}\text { Feed consumption } \\
(\mathrm{gm})\end{array}$ \\
\hline T1 & 231.5 & 223.5 & 854.5 & 232.5 & 224.5 & 840.9 \\
\hline $\mathbf{T 2}$ & 229.3 & 221.3 & 861.3 & 234.6 & 226.6 & 838.1 \\
\hline T3 & 223.8 & 215.3 & 851.5 & 236.1 & 228.1 & 841.8 \\
\hline T4 & 237.7 & 229.7 & 862.5 & 233.9 & 225.9 & 853.1 \\
\hline Means & 230.6 & 222.4 & 857.4 & 234.3 & 282.8 & 843.5 \\
\hline
\end{tabular}

Table, 3: Effect of treatments in Feed Conversion ratio (Kg feed /Kg gain) Dressing percentage and Mortality rate

\begin{tabular}{|c|c|c|c|c|c|c|c|}
\hline & \multicolumn{3}{|c|}{ Brown Strain } & \multicolumn{3}{c|}{ Black Strain } \\
& $\begin{array}{c}\text { F C R } \\
(\mathbf{K g} / \mathbf{K g})\end{array}$ & Dressing \% & $\begin{array}{c}\text { Mortality } \\
\text { rate \% }\end{array}$ & $\begin{array}{c}\text { F C R } \\
(\mathbf{K g} / \mathbf{K g})\end{array}$ & $\begin{array}{c}\text { Dressing } \\
\%\end{array}$ & $\begin{array}{c}\text { Mortality } \\
\text { rate \% }\end{array}$ \\
\hline T1 & $\mathbf{3 . 8 2 2}$ & $\mathbf{7 7 . 6 8}$ & $\mathbf{4 . 2 9}$ & $\mathbf{3 . 7 4 4}$ & $\mathbf{7 7 . 3 5}$ & $\mathbf{4 . 2 9}$ \\
\hline T2 & $\mathbf{3 . 8 9 1}$ & $\mathbf{7 6 . 8 4}$ & $\mathbf{5 . 7 1}$ & $\mathbf{3 . 6 9 8}$ & $\mathbf{7 6 . 5 4}$ & $\mathbf{2 . 8 6}$ \\
\hline T3 & $\mathbf{3 . 9 5 4}$ & $\mathbf{7 7 . 9 1}$ & $\mathbf{4 . 2 9}$ & $\mathbf{3 . 6 9 0}$ & $\mathbf{7 6 . 8 2}$ & $\mathbf{5 . 7 1}$ \\
\hline T4 & $\mathbf{3 . 7 5 4}$ & $\mathbf{7 6 . 8 5}$ & $\mathbf{2 . 8 6}$ & $\mathbf{3 . 7 4 3}$ & $\mathbf{7 7 . 6 7}$ & $\mathbf{2 . 8 6}$ \\
\hline Means & $\mathbf{3 . 8 5 5}$ & $\mathbf{7 7 . 3 2}$ & $\mathbf{4 . 2 9}$ & $\mathbf{3 . 7 1 9}$ & $\mathbf{7 7 . 0 9}$ & $\mathbf{3 . 9 3}$ \\
\hline
\end{tabular}

Table, 4 revealed the absence of differences between treatments or strain in H.D\% egg production, egg weight and feed conversion ratio. These effects may be due to the fact that the replacement of sorghum ration was isocaloric and that the tannin of the sorghum had no effects on the absorbed nutrients from intestine, Also it had no effects on the metabolizable energy, and no effects of sorghum tannins on egg production and egg quality depends on the composition of the diet and in particular, the protein content (25). The diets used were isonitrogenous. These results were agreed with (26). Table (5) showed no differences between treatments and strains in egg shape index and shell weight and thickness as well as the egg quality parameters and blood picture ( $\mathrm{Hb}$ and $\mathrm{PCV}$ ) in black and brown quail strains because the sorghum tannin was low and thus didn't affect the amino acids and some minerals availability, so cation-anion balance of blood 
didn't change and $\mathrm{HCO} 3$ availability and shell thickness didn't reduce (27). In conclusion, the study revealed that the possibility of the
$50 \%$ corn replacement by sorghum alone or with different levels of methionine didn't affect adversely the productive parameters.

Table, 4: Effect of treatments egg production, egg weight, feed convertion ratio.

\begin{tabular}{|c|c|c|c|c|c|c|}
\hline \multirow[t]{2}{*}{ Treatments } & \multicolumn{3}{|c|}{ Brown Strain } & \multicolumn{3}{|c|}{ Black Strain } \\
\hline & $\begin{array}{c}\text { Egg } \\
\text { production } \\
\text { HD\% }\end{array}$ & $\begin{array}{c}\text { Egg } \\
\text { weight } \\
\text { (gm) }\end{array}$ & $\begin{array}{l}\text { F C R } \\
(\mathrm{Kg} / \mathrm{Kg})\end{array}$ & $\begin{array}{c}\text { Egg } \\
\text { production } \\
\text { HD } \%\end{array}$ & $\begin{array}{c}\text { Egg weight } \\
\text { (gm) }\end{array}$ & $\begin{array}{l}\text { F C R } \\
(\mathrm{Kg} / \mathrm{Kg})\end{array}$ \\
\hline T1 & 81.53 & 10.94 & 3.395 & 82.01 & 10.58 & 3.259 \\
\hline $\mathbf{T 2}$ & 81.24 & 10.86 & 3.549 & 81.68 & 11.10 & 3.437 \\
\hline T3 & 81.67 & 10.97 & 3.350 & 81.59 & 10.58 & 3.269 \\
\hline T4 & 81.16 & 11.06 & 3.453 & 81.70 & 10.79 & 3.542 \\
\hline Means & 81.40 & 10.96 & 3.437 & 81.75 & 10.76 & 3.376 \\
\hline
\end{tabular}

Table, 5: Effect of treatments in egg quality and some blood parameters for brown and black quail strain.

\begin{tabular}{|c|c|c|c|c|c|c|c|c|}
\hline \multirow[t]{2}{*}{ Parameters } & \multicolumn{4}{|c|}{ Brown Strain } & \multicolumn{4}{|c|}{ Black Strain } \\
\hline & T1 & $\mathbf{T} 2$ & T3 & T4 & T1 & $\mathbf{T} 2$ & T3 & T4 \\
\hline Egg Shape Index & 1.35 & 1.31 & 1.36 & 1.32 & 1.34 & 1.33 & 1.36 & 1.32 \\
\hline Shell Weight (gm) & 1.56 & 1.64 & 1.59 & 1.63 & 1.56 & 1.64 & 1.59 & 1.63 \\
\hline Shell Thickness (mm) & 0.31 & 0.33 & 0.34 & 0.32 & 0.29 & 0.34 & 0.29 & 0.30 \\
\hline Albumin Height (mm) & 3.96 & 3.91 & 3.87 & 3.82 & 3.85 & 3.90 & 3.89 & 3.84 \\
\hline YolkDiameter (mm) & 20.13 & 20.25 & 20.83 & 20.61 & 20.34 & 20.71 & 20.65 & 20.53 \\
\hline Yolk Height (mm) & 10.56 & 10.64 & 10.68 & 10.52 & 10.61 & 10.59 & 10.67 & 10.61 \\
\hline Glucose $(\mathrm{mg} / 100 \mathrm{ml})$ & 211.5 & 217.6 & 218.4 & 214.8 & 214.7 & 215.7 & 216.9 & 215.7 \\
\hline Triglyceride $\mathbf{m g} / \mathbf{1 0 0 m l}$ & 698.2 & 684.9 & 684.9 & 681.6 & 688.7 & 685.7 & 679.5 & 683.3 \\
\hline Total protein $\mathrm{g} / 100 \mathrm{ml}$ & 3.81 & 3.89 & 3.51 & 3.64 & 3.83 & 3.75 & 3.73 & 3.69 \\
\hline PCV volume \% & 44.26 & 43.95 & 44.27 & 44.67 & 44.52 & 43.87 & 44.61 & 44.73 \\
\hline Hemoglobin gm/100ml) & 10.53 & 10.71 & 10.83 & 10.27 & 10.77 & 10.69 & 10.78 & $\mathbf{1 0 . 5 3}$ \\
\hline ALT(GPT) unit/ml & 20.11 & 20.12 & 20.13 & 20.13 & 21.11 & 21.20 & 20.87 & 21.01 \\
\hline AST(GOT) unit/ml & 120.8 & 121.2 & 121.1 & 121.2 & 121.2 & 122.1 & 121.9 & 122.3 \\
\hline
\end{tabular}

\section{References}

1. Guo, R. and Chen, K. (1995). Tannin in the diets of monogastric animals. China Feed. 19: 18-20.

2. Elkin, R. G.; Arthur, E.; Hamaker, B.; Axtell, J. D.; Douglas, M. W. and Parsons, C. M. (2002). Nutritional value of highly digestable Sorghum cultivar for meat type chickens. J. Agric. Food Chem., 50:41464150.

3. Ebadi, M. R.; Pourrezza, J.; Jamalian, J.; Edriss, M. A.; Samie, A. H. and Mirhadi, S. A. (2005). Amino acid content and availability in low, medium and high tannin sorghum grain for poultry. Int. Sci., 4(1): 27-31.

4. Mansoori, B. and Acamovic, T. (2007). The effect of tannic acid on the excretion of endogenoud methionine, histidine and lysine with broiler. Anim. Feed Sci. Technol., 134:198-210.
5.Zhou, W. and Ni, S. C. (1990). Effects of tannin on the activities of digestive enzymes and utilisation of amino acids. Feed Panorama, 2: 7-10.

6. Li, Y. and Zhang, Y. (1998). The effects of sorghum tannin on utilisation of nutrients. Chinese Ani. Magazine. 34 (4): 24-25

7. Schutte, J. B.; Jong, W. S. and Pack, M. (1997). Replacement value of betaine for DLmethionine in male broiler chicks. Poult. Sci., 76: 321-325.

8. Ojano-Dirain, C. P. and Waldroup, P. W. (2002). Evaluation of lysine methionine and threionine needs of broiler three to six week of age under moderate temperature stress. Poult. Sci., 1(1): 16-21.

9. N.R.C. (1994). Nutrient of domestic animals. L. Nutrient Requirement of Poult. Acad. Sci., Washington D.C. 
10. A.O.A.C. (1980). Association of Official Analytical Chemists. Official Methods of Analysis Washington, D.C.

11. Steel, R. C. and Torrie, J. H. M. (1960). Principles and Procedures of Statistics, 2nd ed. Mc Graw- Hill Book Co. New York, N .Y. USA, Pp: 481.

12. SAS. (2000). Statistical Analysis Systems, User's Guide Version 6, $4^{\text {th }}$ ed. SAS Institute Inc., Cary, North Carolina, USA

13. Duncan, D. B. (1955). Multiple Ranges and multiple F- test. Biometrics.11: 1- 42.

14. Garicia, R. G.; Meudesaud, A. A. and Audrade, C. D. (2005). Evaluation of performance and gastric parameters of broiler chickens fed diets formulated with sorghum with and without tannis. CIênc. Agrotec., Lavras, 29(6):1248-1257.

15. Nyanoor, E. K. ; Dedokum, A. A.; Hamaker, B. R.; Ejeta, G. and Adeola, O. (2007). Nutritional evalution of high-digestible sorghum for pigs and broiler chicks. J. Anim. Sci., 85:196 -203.

16. Adama, T. Z.; Ogunbajo, S. A. and Mambo, M. (2007). Feed intake, growth Performance and nutrient digestibility of broiler chicks fed Diets containing varying levels of sorghum dried brewers Grains. Inter. J. Poult. Sci., 6(8):592-598.

17. Torki, M.; Farahm, M. and Pour, E. (2007). Use of dietary enzyme inclusion and seed germination to improve feeding value of sorghum for broiler chicks. World Poult. Sci. Asso., 26 (30): 643-646.

18. Salissou, I. (2009). Nutritional value of sorghum for poultry feed in West Africa. Ph.D. Thesis, Department of Animal Sciences and Industry, College of Agriculture Kansas State University. Manhattan Kansas. USA.

19. Lu, J.J.; Huang, C.W. and Chou, R. G. (2003). The effects of DL-Methionine and DL-Methionine hydroxy analogue on growth performance, contents of serum amino acids and activities of digestive proteases in broilers. Asian-Aust. J. Anim. Sci., 16(5): 714-718.

20. Chamruspollert, M.; Pesti, G. M. and Bakalli, R. I. (2004). Influence of temperature on the Arginine and Methionine requirements of young broiler chicks. Poult. Sci., 13: 628-638.

21. Leal, A. M. (2005). Methionine sources do not affect performance and carcass yield of broilers fed vegetable diets and submitted to cyclic heat stress. Poult. Sci., 7(3): 159-164.

22. Gorman, I. and Balnave, D. (1995). The effect of dietary lysine methionine concentration on the growth characteristics and breast meat yields of Australian broiler chickens. Agric. Res., 46: 1569-1577.

23. Bunchasak, C.; Santoso, U.; Tanaka, K.; Ohtani, S. and Cristino, C. M. (1997). The effect of supplementing Methionine plus cysteine to a low-protien diet on the growth performance and fat accumulation of growing broiler chicks. 10(2): 185-191.

24. AL-Tammee, N. k. A. (2010). Effect of replacement crude and germinated sorghum instead of yellow corn in the productive performance and some biochemical parameters of broiler. M. Sc. Thesis. Collage of agriculture and forestry .University of Mosul.

25. Nyachoti, C. M.; Atkinson, J. L. and Leeson, S. (1997). Sorghum tannins: A review. World's Poult. Sci. J., 53: 5-21.

26. Faquinello, p.; Murakami, A. E.; Cella P. S.; Franco J. R. G.; Sakamoto, M. I. and Bruno L. D. G. (2004). High tannin sorghum in diets of Japanese quails (Coturnix coturnix japonica) Rev. Bras. Clenc. Avi., 6(2) :1-7.

27. Sell, D. R. and Rogler, J. C. (1984). The effect of sorghum tannin and methionine level on the performance of laying hens maintained in two temperature environment. Poult. Sci., 63:109-116. 
تأثير إستعمال الذرة البيضاء و الميثايونين في الاداء الانتاجي والصفات النوعية لبيض التفقيس لسلالتين

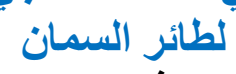

\section{دريد ذنون يونس الزيان}

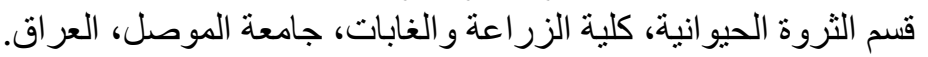

E-mail:duraidthonnon@yahoo.com

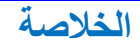

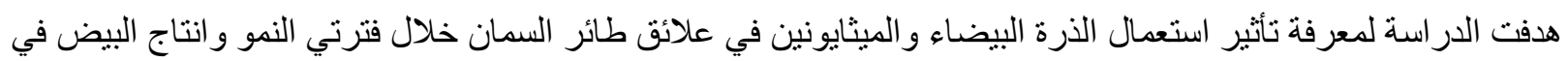

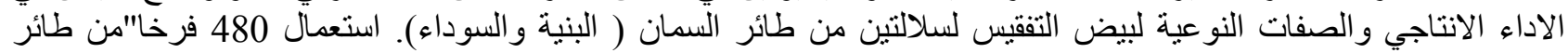

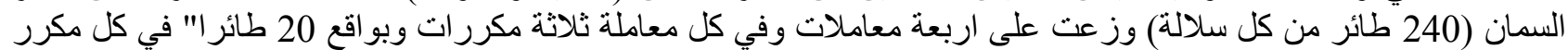

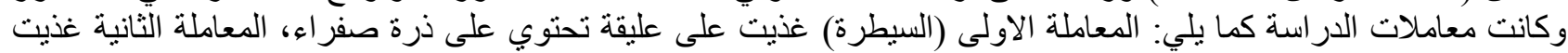

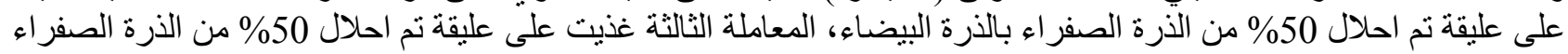

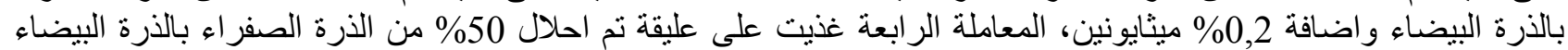

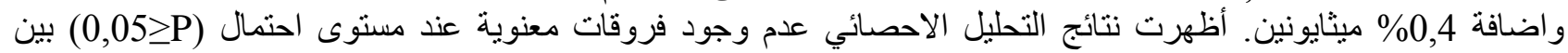

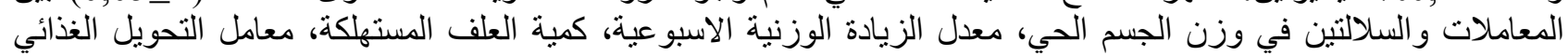

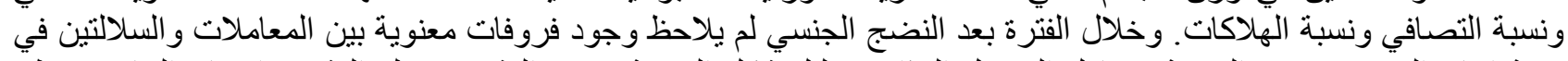

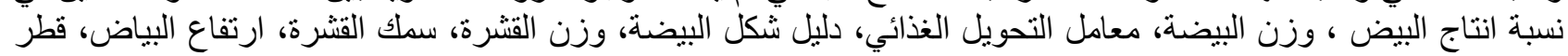

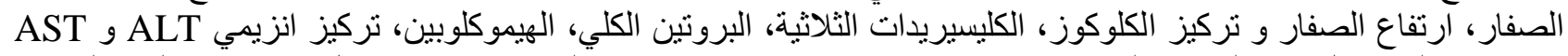

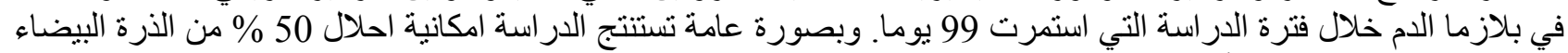
محل الذرة الصفر اء دون التأثير على التصفات الانتاجية مما يؤدي التى التقليل من تكاليف الانتاج .

الكلمات المفتاحية: الذرة البيضاء، التانين، سلالة السمان، مقاييس الدم، الصفات النوعية للبيض . 